\title{
Purchasing Power Parity Approach to Exchange Rate Misalignment in Nigeria
}

\author{
Musa Nakorji ${ }^{1,2}$, Ngozi T. I. Agboegbulem ${ }^{2}$, Blessing A. Gaiya ${ }^{2}$, and Ngozi V. \\ Atoi $^{2}$.
}

This study examines the purchasing power parity $(P P P)$ approach to the determination of exchange rate misalignment in Nigeria by using two variants of the PPP: the absolute PPP (aPPP) and the relative PPP (rPPP). Data on the Nigerian Naira to US Dollar (N/\$), British Pound (N/£) and Chinese Yuan (N/\#) interbank exchange rates, Nigeria consumer price index and Inflation as well as the US, UK and China consumer price indices and inflation rates spanning 2008:M1 to 2018:M12 were utilized. A recently modified fractional cointegration framework was employed, taking care of smooth structural breaks and nonlinearity, while the unit root tests employed the fractional alternatives. The results confirmed that the aPPP approach to exchange rate determination is unrealistic but revealed empirical support for the rPPP approach. Furthermore, the exchange rates computed with the rPPP approach show that the interbank Naira to US Dollar, UK Pounds and Chinese Yuan exchange rates were overvalued in most of the period of this study. The period of undervaluation observed in June 2016 and April 2017 coincided with the periods when CBN introduced the investors and exporters window. The study recommends the use of rPPP for gauging the level of exchange rate misalignment in Nigeria and suggests the need to diversify the export base to appreciate the exchange rate.

Keywords: Exchange rate, overvaluation, undervaluation, purchasing power parity

JEL Classification: C3, C5, C13

DOI: $10.33429 /$ Cjas. $12121.3 / 6$

\section{Introduction}

The exchange rate measures the value of a currency in relation to another and is said to be in equilibrium when the demand for a currency equals its supply. Any deviation from this equilibrium rate is referred to as a misalignment, in which case,

\footnotetext{
${ }^{1}$ Corresponding Author: mnakorji@cbn.gov.ng

${ }^{2}$ Authors are staff of Economic Policy Directorate, Central Bank of Nigeria. The views expressed in this paper are those of the authors and do not represent those of the Central Bank of Nigeria
} 
the exchange rate could be either overvalued or undervalued. Exchange rate misalignments could impinge on an economy causing distortions in various sectors by influencing the capital accumulation process and affecting the competitiveness of the tradable sector in relation to other countries (Ali et al., 2015). Literature on exchange rates has showed that misalignment can be measured using either price-based criteria such as the purchasing power parity (PPP), model-based criteria of nominal exchange rates, or solvency and sustainability-based criteria (Qayyum et al. 2004).

As a price-based theory of exchange rate determination, the PPP focuses on changes in price levels, as the overriding determinant of exchange rates. The World Bank (2013) expressed PPP as the number of currency units required to purchase several goods and services equivalent to what can be purchased with one unit of currency of the referenced country. The PPP is thus, simply a theory of exchange rate determination used for comparing standard of living, evaluating productivity levels, and determining relative values of currencies across countries (Lafrance \& Schembri, 2002). For the basis of comparison, Lafrance \& Schembri (2002) noted that PPP exchange rates computed by comparing the prices of national consumption baskets are used to translate per capita national incomes into a common currency.

Exchange rates deviate from PPP due to distortions in domestic and foreign prices as a result of some factors (Qayyum et al., 2004). The factors include: (i) restrictions on trade and capital movements; (ii) speculative activities and official intervention; (iii) productivity bias between tradable and non-tradable goods which could result in systematic divergence of internal prices; (iv) sticky prices which do not move fast enough to offset changes in the nominal exchange rates and real shocks to the economy such as large commodity price changes, financial sector innovation, productivity growth differentials among countries and budget imbalances.

Exchange rate determination using the PPP theoretical approach has been a subject of debate since the early 1970s (Taylor \& Taylor, 2004). The interest in PPP rests on its practical application to comparative exchange rate policy-making models (Engel et al., 2012.) and theoretical exchange rate determination frameworks (Cerrato et al., 2013). In most cases, empirical findings on the validity of PPP depends on the variant of PPP used - absolute PPP (aPPP) or relative PPP (rPPP). Taylor and 
Taylor (2004) posit that the rPPP holds whenever the aPPP holds, but the reverse relationship does not hold. However, there seems to be many empirical evidence confirming the failure of aPPP (Glenvill, 2013; Wickremasinghe, 2004; Salvatore, 1993; Crownover, 1996), while others provide empirical supports for the long-run rPPP (Kalsoom 2014; Stephen \& Sanni, 2011; Coakley \& Snaith, 2004; Alpher $\&$ Kula, 2007). In most economies where long-run PPP theory holds, it helps to determine the extent to which a currency is misaligned (over- or under-valued). AlZyoud (2015) argued that a decline (rise) in a country's domestic purchasing power will be connected to a proportionate depreciation (appreciation) of its currency on the foreign exchange market to reflect the PPP. This implies that where the foreign exchange market does not respond correspondingly to the decline (rise) in the purchasing power, then the exchange rate becomes inappropriate or misaligned.

Exchange rate misalignment has been a major concern to policy makers in Nigeria due to its adverse effects on the economy. The foreign exchange market has come under intense pressure leading to the depreciation of the Naira and the widening of the premium between the inter-bank exchange rate and the Bureau de Change (BDC) rate. In a bid to realign the exchange rate, the Central Bank of Nigeria (CBN) embarked on several policy measures which included moving to a more flexible exchange rate regime in June 2016. Furthermore, to deepen the foreign exchange market and narrow the premium, the $\mathrm{CBN}$ introduced the Investors and Exporters (I\&E) window, primarily to boost liquidity in the market and ensure timely execution and settlement of eligible transactions. Also, other specialized Secondary Market Intervention Sales (SMIS) were introduced to reduce demand pressure and moderate the price of the Naira.

Given the developments in the foreign exchange market and the need to realign the exchange rate, this study seeks to determine if the PPP holds in Nigeria and to determine the level of overvaluation/undervaluation of the exchange rate using the pricebased PPP approach. Methodologically, we use the new advancement in the time series unit root testing known as the Nonlinear Fourier Fractional Unit Root (NFFUR) to achieve the objective of the study. This technique was first developed by Robinson (1994) and further modified by Gil-Alana and Yaya (2020) to account for 
smooth structural breaks as against abrupt changes (instantaneous breaks) of Perron (2006). Studying the real exchange rate behavior within the concept of nonlinearity and regime shift in a fractional unit root framework will provide a more comprehensive insight into the validity of PPP since fractional integration approach is a more general approach with appealing properties compared to classical unit root testing (Diebold \& Rudebusch, 1991; Hasslers \& Wolters, 1994). Also, a co-integration test of long-run PPP using mean-reverting residuals of the functional relation of real exchange rates and relative prices is applied to the data. The data for the analyses span from January 2008 to December 2018 for Nigerian Naira to US Dollar (N/\$), British Pound $(\mathrm{N} / £)$ and Chinese Yuan $(\mathrm{N} / \mathrm{Y})$ interbank exchange rates, Nigeria consumer price index and Inflation rate as well as the US, UK and China consumer price indices and inflation rates. The level of misalignment is derived from the deviation of the nominal interbank exchange rate from the validated and computed PPP.

The rest of the study is organized as follows: Section 2 presents the literature review, and the methodology is explained in Section 3. The study results are discussed in Section 4, while Section 5 concludes the paper with some recommendations.

\section{Literature Review}

\subsection{Theoretical Literature}

A misaligned exchange rate is defined as an exchange rate which is inconsistent with a satisfactory balance of payments (Oxford Reference, 2021). Exchange rate misalignment affect the competitiveness of a country by changing the foreign prices of exports (thus influencing the decision of other countries to patronize home goods) and also the domestic prices of imports (UNCTAD, 2012). Thus, an overvalued exchange rate makes imports very attractive because less of the domestic currency is needed to purchase foreign goods but makes domestic exports hard to sell thus affecting competitiveness, creating current account deficits and creating global imbalances. On the other hand, an undervalued exchange rate makes exports very cheap, thereby encouraging foreigners to buy domestic exports. This tends to result in a current account surplus. Many approaches have been developed to determine a proper or equilibrium exchange rate and arrive at conclusions on the currency's misalignment. The real purchasing power parity is one of the most widely used approaches to deter- 
mining exchange rate misalignment and has its foundations on the Law of One Price. The law of single price (LoP) is the central premise of the PPP condition and posits that if prices are represented in terms of the same currency, the same good should have the same price across countries. This definition only applies if the items are homogenous and such costs as shipping or tariffs can be ignored (Pakko \& Pollard,1996; Krugman, 1978; Israd, 1977).

A single price across countries relies on the arbitrage between them. If the prices of similar items are varied in a manner that the external costs were paltry, then the arbitrage opportunity would exist, until the price differential is eliminated among such similar goods over time because of the laws of supply and demand. Specifically, lower-priced goods would give rise to excess demand and this will eventually lead to an increase in prices while higher prices will lead to an excess supply of goods and this will eventually lead to a fall in prices to an extent that the price differential in both countries becomes zero and the arbitrage is eventually wiped out. According to Carnovole (2001), the LoP can be mathematically represented as:

$$
S=b \frac{P}{P *}
$$

From equation 1, $\mathrm{P}$ and $\mathrm{P}^{*}$ are the prices for an identical commodity in the homeland and foreign country, respectively; $\mathrm{S}$ is the spot exchange rate and $\mathrm{b}$ is an arbitrary constant. It therefore, implies that the spot exchange rate can be presented as the ratio of two nominal variables. There are two different versions of PPP: the aPPP and the rPPP.

From the foregoing, the PPP has been featured continuously in the literature as the appropriate criteria for the analysis of the equilibrium exchange rate, and its analysis is segmented into two main perspectives in Officer (2006). 


\section{Absolute Versus Relative PPP}

\section{Absolute PPP (aPPP)}

The aPPP states that the nominal exchange rate between two currencies should be equal to the ratio of aggregate price levels between the two countries such that a unit of currency of one country will have the same purchasing power in a foreign country. The theory, therefore, provides that the "correctness" of the actual nominal exchange rate, based on the prices of homogeneous products in different countries, can be measured. The aPPP is premised on certain assumptions, which include that; (i) all goods are identical and tradable; (ii) no barriers to trade exist, (iii) nonexistence of transportation costs, taxes, and tariffs; and (iv) perfect market information exists. The aPPP predicts that price levels and cost of living will be the same across countries. The aPPP holds if the same basket of goods costs the same when prices are converted to a common currency.

The basic distinction between the law of one price and the aPPP is that applies the aggregate price levels rather than the price of one particular commodity. The definition of PPP can therefore be slightly altered to state that, once converted into the same currency, the general prices in the two economies would move towards convergence over time. Given that the price indices are commonly employed to represent the general price levels, the aPPP can be presented mathematically as (Haiko, 1992; McChesney et al., 2004):

$$
S=b \frac{c p i}{c p i *}
$$

where; $b$ is the discretional constant, that represents shifts in exchange rates; $S$ is the nominal spot exchange rate; and cpi and cpi* represent the price indices for the homeland and foreign country, respectively.

The aPPP hypothesis has several drawbacks (Phiri, 2014). First, the theory is based on the one-price rule and has been proven not to hold (McChesney et.al., 2004). Second, many countries employed weak indexes to measure price levels. As a result, the simplified ratio of price levels cannot be an appropriate approach to measure the equilibrium exchange rates (Haikko, 1992). Third, factors such as tariffs, transport 
costs and varying rates of adjustment in the products and foreign exchange markets could facilitate more divergence of exchange rate from aPPP (Shirley, 2013). In view of these shortcomings, most research scholars and economists have shifted the premise of analysis to the relative variant of PPP theory.

\section{Relative PPP (rPPP)}

The rPPP also focuses on the relationship between prices and exchange rates. It is said to hold when the inflationary adjustments between two countries corresponds with the depreciation of a country's currency relative to other countries. Alternatively stated, the rPPP model is concerned with the rate of change in the exchange rate in a manner that variations in nominal exchange rate move in an inverse direction with the inflation between the two countries. Specifically, the percentage change in the nominal exchange rate should be equal, but opposite in direction to the difference in the rates of inflation between countries.

Drawing from Suranovic (1999), the rPPP is usually referred to as the dynamic version of the PPP and can be expressed as;

$$
\underbrace{\frac{\Delta E_{\mathrm{N} / \$, t}}{E_{N / \$, t}}}_{\text {Rate of depreciationof the nominal exchange rate }}=\underbrace{\pi_{i, t}-\pi_{i *, t}}_{\text {Inflation differential }}
$$

where $\pi_{i, t}$ and $\pi_{i^{*}, t}$ represent the inflation rate of the domestic and foreign country, respectively. The $\Delta E$ stands for change in the spot exchange rate and $E$ is the spot exchange rate. Thus, the rate of depreciation of the nominal exchange rate equals the difference between the inflation rates of two countries (the inflation differential).

\subsection{Empirical Literature}

Several empirical studies have tested the validity of the PPP approach in the determination of the appropriate exchange rate and establishment of exchange rate misalignment across various countries and using various techniques. From a global perspective, Voinea (2013) analyzed the validity of the PPP before and after the Global Financial Crisis (GFC) for the UK, Canada, Japan, and the Eurozone in relation to the US dollar from January 1980 to March 2013. Using unit root and Engle-Granger 
cointegration tests, aPPP was found to hold in the long-run for only the Euro at a 5 percent confidence interval during the crisis period. The ADF unit root test found evidence in favour of rPPP during the crisis period for the UK at 1 percent, and for the euro and yen at a 5 percent confidence interval. Alba and Papell (2007) used panel data methods to test for unit roots in 84 countries and found very strong evidence of PPP in countries that are open to trade. Such countries also registered lower inflation and moderate nominal exchange rate volatility. Furthermore, they observed that such countries have similar economic growth rates to that of the United States. In the same vein, Coakley and Snaith (2004) tested the long-run rPPP for the period 1977:M1 - 2001:M12 for 15 European countries and concluded that long-run rPPP holds for the 15 countries. Using monthly data for the black-market rate and official exchange rate for the period 1969 to 1998, Alpher and Kula (2007) also examined the validity of the PPP in Turkey by employing the unit root test. The results support the PPP hypothesis in Turkey.

Similarly, Islam and Ahmed (1999), and Zayed and Zahan (2017) used cointegration tests for the Korea-US exchange rate and prices and Bangladesh economy respectively. Their results show that a long run relationship exists between exchange rate and inflation. Islam and Ahmed's (1999) study revealed a slow but reasonable speed of adjustment with the empirical results showing only partial support for the PPP hypothesis for Korea. In the case of Zayed \&Zahan (2017) findings show that the real exchange rate, import, and inflation accounts for deviation in PPP in Bangladesh.

Crownover et al., (1996) employed OLS, Fully Modified OLS (FM-OLS), and unit root techniques to test the aPPP using annual data from 1972 to 1992. They found support for rPPP in eight of fifteen countries and aPPP in four of eight countries. However, Salvatore (1993) and Crownover et al. (1996) noted that the aPPP theory can be inapplicable due to the existence of transportation costs, non-traded goods, or other obstructions to the free flow of international trade.

Several other studies however failed to validate the PPP as an approach for exchange rate determination as they found that PPP did not hold. Al-Zyoud (2015) examined the long-run relationship between the US dollar and the Canadian dollar exchange rates by employing the Engel-granger cointegration test for the period 1995:M1 to 
2008:M8, and observed that in the long-run, the aPPP does not hold. The author attributed the lack of long-run relationships to the small sample size. However, the study acknowledged the significance of the relative price movement in explaining the exchange rate of the US dollar against the Canadian dollar. Testing PPP hypothesis in Sri Lanka, Wickremasinghe (2004) used exchange rates for six foreign currencies for the period 1986:M1 to 2000:M11. Unit root test and error correction model, non-stationarity of the exchange rates was observed thereby violating the necessary conditions for the PPP to hold. The symmetry and proportionality hypotheses implied by the PPP were rejected. The study concluded that the PPP hypothesis is not valid for Sri Lanka. Baharumshah and Ariff (1997) used a cointegration approach with quarterly data from 1975 to 1996 for Southern East Asian countries and found that there exists no relationship for all countries even when the absolute version of the PPP hypothesis was tested using lower frequency data. In the same vein, BahmaniOskooee (1993) used quarterly data for 25 Less Developing Countries over the period 1973 - 1988 and found little empirical support for the PPP.

Taylor and Taylor (2004) did a study to test relative and absolute PPP for the U.S and U.K, using CPI data over the period 1820-2001 and producer price indices, for the period 1791-2001. By randomly normalizing each of the series to zero in 1900, they found that aPPP did not hold perfectly and continuously. When the national price levels of the two countries are expressed in a common currency, they tend to exhibit a positive relationship over a long period. The correlation between the two national price levels is much greater when producer prices are factored in than when consumer prices are accommodated. Using monthly data from 2001:M3 to 2015:M10, Yildirim (2017) investigated the PPP validity in Turkey with respect to its four main trading partners namely Russia, the European Union, the US, and China. The study used a nonlinear unit root test, which revealed that nonlinear unit root tests showed stronger evidence in support of the PPP hypothesis compared to the conventional unit root test on the condition that nonlinearities in the exchange rate are correctly specified.

In Africa, Zerihun and Breitenbach (2016) use the non-parametric test and the Fourier stationarity test to confirm the non-linear nature of real exchange rates in the Southern African Development Community (SADC). This was motivated by the SADCs 
Purchasing Power Parity Approach to Exchange Rate Misalignment in Nigeria

Nakorji et al.

monetary integration agenda and the need to understand whether PPP holds as one of the criteria for a modern optimal currency area. The Fourier test confirms the existence of an optimal currency area and serves as an encouragement for the integration initiatives in the SADC region. Rawlins and Glenvill (2013) investigated the longrun PPP using unit root and cointegration tests on data for South Africa and its five trading partners from 1971 to 2012. The study produced weak evidence in support of the PPP hypothesis. Mohammed (2016) examined the existence of PPP between the Euro and US dollar against the official exchange rate and the black-market exchange rate of the Algerian dinar for the period 2003M1 - 2015M5. The study employed the Johansen cointegration Test, which showed that the official exchange rate does not support the PPP hypothesis and the black-market exchange rate is found to be a better exchange indicator for maintaining stable PPP in Algeria.

Krichene (1998), Kargbo (2003, 2004, 2006), Arize (2011), and Si Mohammed and Maliki (2015) found support for the PPP hypothesis in Africa. Krichene (1998) analyzed cross-sectional data of five East African countries for the period 1979:M1 to 1996: M12. The findings which adopted PPP as a long-term anchor for nominal exchange rates posits that it tends to adjust to inflation differentials. The results indicate that the bilateral real exchange rate has a long-run equilibrium with the PPP. Using the Johansen cointegration technique and ECM, Kargbo (2003, 2004, 2006) examined the validity of PPP in Africa. His 2003 study employed annual data for black market exchange rates and CPI for 30 countries spanning the period 1960 to 1997. This study was extended in 2004 to examine bilateral official exchange rates and the CPI of 35 countries for the period spanning 1958 to 2002 using annual data. Following exchange rate policy reforms on the premise that long-term PPP holds in Africa, Kargbo (2006) reexamines the relationship between PPP and real exchange rate behaviour. The study adopted Johansen's cointegration methodology on the GDP deflators of 40 countries and official and black-market exchange rates annual data from 1958 to 2003. The findings establish support for long-run PPP in Africa, implying that PPP is a dependable guide for exchange rate reforms and determination. Using the panel error correction model (PECM) on monthly data for the period 2003:M1 to 2015: M5, Si Mohammed and Maliki (2015) confirmed that a long-run relationship 
exists between exchange rates and relative prices in foreign countries using panel cointegration. This result was attributable to the validity of PPP for nine major trade partners of Algeria.

Using the Error Correction Model (ECM) on a PPP framework, Ononugbo (2005) examined the long-run relationship between the Naira to US dollar exchange rate and relative price levels in Nigeria and the US between 1970 and 2003. The study accounted for policy switch from exchange rate control to a market-based regime and found that the nominal exchange rate followed the long-run path as suggested by the PPP. Ekong and Onye (2013) used data from 1986 to 2010 and the flexible price monetary model (FPMM), to investigate the long-run PPP relationship. The results reveal that, in the long run, exchange rate and relative prices deviate without bounds and this indicates that the long-run PPP does not hold. Within the Nigerian context, Stephen and Sanni (2011) test the validity of PPP by employing the OLS regression technique for the period 1986 to 2010. Findings show that the PPP is a better option for determining exchange rate misalignments in Nigeria.

Obaseki (1998) employed cointegration techniques to investigate the validity of PPP in determining the Naira exchange rate. He utilized time series data for the nominal exchange rate, CPI for both Nigeria and the United States, parallel market premium, and parallel market exchange rate. Findings from the study showed that the exchange rate as a dependent variable showed a weak relationship on the relevance of PPP to Nigeria. However, the use of the parallel market exchange rate as a dependent variable confirmed the long-run relationship between the exchange rate and relative prices in Nigeria. Arize (2011) used a monthly dataset for the real effective exchange rate (REER) of 66 developing countries from 1980:1 to 2009:10 to examine the purchasing power parity in LDCs. The study employed the panel KwiatkowskiPhillips-Schmidt-Shin (KPSS) and Kapetanios Shin and Shell (KSS) approaches to investigate the stationarity of the REER. The study found significant evidence supporting long-run PPP hypothesis; thus, implying that PPP is a suitable framework for determination of exchange rate and policy formulation around exchange rate reform in the LDCs. Also, the study recommends the use of REER data as well as linear and nonlinear tests with different null hypotheses. 
Juan et al. (2018) appraised the impact of exchange rate misalignment on economic activity in nine Central and Eastern European (CEE) economies. Open macroeconomic models such as interest rate differentials or the Balassa-Samuelson effect based on the country-specific long-run relationship were used as determinants in measuring exchange rate misalignment. The result indicated a substantial reduction in misalignment, which was reversed to a certain degree after 2008. The overvaluation of exchange rates has a negative effect on economic activity. Overall, overvaluation has a more significant effect than undervaluation. The effect of misalignments on economic activity seems to be nonlinear extending to other variables, including institutions. Similarly, Tipoy, Breitenbach and Zerihun (2018), sought to find the impact of misaligned exchange rates on economic growth for a sample of emerging economies using data from 1970 to 2014 and a panel smooth transition regression vector error correction model in addition to a Granger causality test within a nonlinear framework. They found that exchange rate misalignment affects output in both short and long run particularly when the currency is overvalued. They also found that undervaluation can be used as a growth strategy but the benefits get smaller, the larger the undervaluation.

A lot of work has been done on PPP in different jurisdictions. Most of the studies made use of unit root tests and cointegration techniques to test the validity of PPP for exchange rate determination and assessment of misalignment Some of the studies also made use of the OLS and ECM methods, however, most of these methods assume that the data are linear in nature. Yildirim (2017) averred that the use of nonlinear unit root tests delivers stronger evidence in favour of PPP when compared to conventional unit root tests. Testing the validity of PPP using nonlinear unit root tests has not been carried out within the Nigerian context to the best of our knowledge. Hence, this work is a contribution to the empirical literature on exchange rate determination using PPP.

\section{Data and Methodology}

\subsection{Data}

The data used in the analysis were obtained from the International Financial Statistics (IFS) of the International Monetary Fund (IMF) and the Statistical Bulletin of 
the Central Bank of Nigeria. The study covers the period January 2008 to December 2018 and the variables utilized are the Naira to US Dollar (N/\$), British Pound (N/£) and Chinese Yuan(N/Y) interbank exchange rates, Nigeria consumer price index and Inflation $\left(\pi_{N t}\right)$ as well as the US, UK and China consumer price indices and inflation rates. The inflation rate, which is derived from the CPI, refers to the change in the purchasing power of a particular currency, while the CPI is the price of goods. Unlike yearly data where monthly developments are subsumed, these variables are available on a monthly basis, which makes their dynamics over time accessible under the unit root framework and other estimation techniques. The data coverage accommodates the period data are available for the series as at the time this study was proposed, and the long observations enhance the efficiency of parameter estimates. As established in the literature, the aPPP is computed using CPI while the rPPP is determined using the inflation rate alongside the exchange rate of the two countries (Crownover et al., 1996; Sarno \& Taylor, 2002). This is shown and described in Table 1.

Table: 1 Variables Acronyms and Description

\begin{tabular}{|c|c|c|c|}
\hline Variables & Variables Description & Acronyms & Description \\
\hline \multicolumn{4}{|c|}{ aPPP Variable Measured in terms of Consumer Prices } \\
\hline qc’ & $\begin{array}{l}\text { Ratio of Nigeria to China } \\
\text { price indices }\end{array}$ & rc' & $\begin{array}{l}\text { Nigeria Naira to Chinese } \\
\text { Yuan real exchange rate }\end{array}$ \\
\hline qus' & $\begin{array}{l}\text { Ratio of Nigeria to US } \\
\text { price indices }\end{array}$ & rus' & $\begin{array}{l}\text { Nigeria Naira to US Dollar } \\
\text { real exchange rate }\end{array}$ \\
\hline quk' & $\begin{array}{l}\text { Ratio of Nigeria to } \mathrm{UK} \\
\text { price indices }\end{array}$ & ruk' & $\begin{array}{l}\text { Nigeria Naira to UK Pound } \\
\text { real exchange rate }\end{array}$ \\
\hline \multicolumn{4}{|c|}{ rPPP Variables measured in terms of Inflation Rates } \\
\hline $\mathrm{qc}$ & $\begin{array}{l}\text { Ratio of Nigeria to China } \\
\text { inflation rate }\end{array}$ & $\mathrm{rc}$ & $\begin{array}{l}\text { Nigeria Naira to Chinese } \\
\text { Yuan real exchange rate }\end{array}$ \\
\hline qus & $\begin{array}{l}\text { Ratio of Nigeria to US in- } \\
\text { flation rate }\end{array}$ & rus & $\begin{array}{l}\text { Nigeria Naira to US Dollar } \\
\text { real exchange rate }\end{array}$ \\
\hline quk & $\begin{array}{l}\text { Ratio of Nigeria to } \mathrm{UK} \\
\text { inflation rate }\end{array}$ & ruk & $\begin{array}{l}\text { Nigeria Naira to UK Pound } \\
\text { real exchange rate }\end{array}$ \\
\hline
\end{tabular}

\subsection{Approaches to the Study of PPP}

Sarno and Taylor (2002), and Taylor and Taylor (2004) summarized different approaches to testing the validity of the PPP in the short and long run. These include the monetary approach, the theory of exchange rate overshooting, random walk, unit 
root, and cointegration approaches.

Monetary Approach was the dominant approach to the determination of exchange rate in the early 1970s. The approach supports the validity of the PPP exchange rate (Frenkel, 1976; Taylor, 1995; Frankel \& Rose, 1995). Proponents of monetary approach opined that because the exchange rate is one country currency relative to another country's currency, relative prices should be determined by the relative balance of supply and demand in the respective money and asset markets. This approach was tested empirically, and the results show that, in the long-run, the continuous PPP holds while the same is not applied in the short-run.

The theory of exchange rate overshooting was a reaction to the failure of the PPP in the short run. This approach explains that PPP is retained as a long-run equilibrium while allowing for significant short-run deviations due to sticky prices (Dornbush, 1976). This was also tested empirically, and evidence showed that long-run PPP also showed some weaknesses.

The main proponents of the random walk test for long-run PPP were Roll (1979) and Adler and Lehmann (1983). In this approach, the real exchange rate does not revert to its mean level, but follows a random walk. It assumes international markets are efficient in reflecting all available information and arbitrage opportunities are quickly exploited. Empirically, the results that support a random walk was at best mixed and results depended on the criteria employed (Cumby \& Obstefield, 1984).

Most studies that applied unit root hypothesis testing assumed a linear framework, particularly, the Dickey and Fuller (DF) (1979) and its augmented version (the ADF) in Dickey and Fuller (1981) unit root test techniques (Roll, 1979; Frankel, 1986; Nusair, 2003; Aslan \& Kula, 2007; Merza, 2017). These tests attempt to investigate whether the path of the real exchange rate over time returns to its average level. The idea behind this approach is, if the real exchange rate has a unit root, then it may never really settle in the long run.

However, Frankel (1986 and 1990), Taylor (1988), and Mark (1990) noted that ADF technique is inadequate to reject a null hypothesis and uphold the PPP because of low power. This problem can be worsened in the presence of structural changes in 
the series because these techniques are not built to capture the effects of regime shift inherent in the long financial time series such as exchange rate. Also, the power of these unit root tests is considered weak because they do not accommodate fractional unit root alternatives (Diebold \& Rudebusch, 1991; Hasslers \& Wolters, 1994; Lee \& Strazicich, 2013). To circumvent these inadequacies, the ADF is transformed into Fourier ADF (FADF) by Enders and Lee (2012a and 2012b) and Fourier ADFBreak point (FADF-SB) by Furuoka (2017). These modifications are developed to overcome the problem of nonlinearity and structural breaks since the Fourier function induces smooth transitioning of breaks. In other words, FADF-SB accounts for both smooth and instantaneous breaks. As pointed out in Kilian and Taylor (2003), nonlinearity in the real exchange rate can arise from the influence exerted by heterogeneous agents like economic fundamentalists, technical analysts, and noise traders in the foreign exchange market. Furthermore, the official foreign exchange intervention could cause nonlinearity in real exchange rate movements (Taylor, 2002).

The newest advancement in the unit root testing is the development of nonlinear Fourier fractional unit root (NFFUR). The NFFUR with breaks simultaneously account for structural changes and nonlinearity in the real exchange rate, and detects smooth breaks against abrupt changes. Studying the real exchange behavior within the context of nonlinearity and regime shift in a fractional unit root framework provides a more comprehensive insight into the validity of the PPP.

\subsection{Model Specification}

The advancement in testing the null hypothesis of a unit root in a time series, $r_{t}$ evolved from the popular DF unit root general specification, given as,

$$
r_{t}=\mu+\rho\left(r_{t-1}\right)+\varepsilon_{t}
$$

where $r_{t}$ represents the real exchange rate between Naira and foreign currencies that Nigeria external reserve is held (US Dollar, UK Pound, and China Yuan) at time $t$. The notations $\mu$ and $\varepsilon_{t}$ denote the constant and the error terms, respectively, while $\rho$, representing the slope parameter for the lagged dependent variable $\left(r_{t-1}\right)$ is unity whenever $r_{t}$ is a random walk (unit root). The first difference transformation of (4) 
Purchasing Power Parity Approach to Exchange Rate Misalignment in Nigeria

Nakorji et al.

produces $\Delta r_{t}=\mu+(\rho-1) r_{t-1}+\varepsilon_{t}$, given that $\Delta=(1-B)$ and $B$ is the backward shift operator.

\subsubsection{Fourier Alternative Hypotheses of ADF Unit Root Test Modifications}

The general alternative hypothesis specification of the null in (4) with constant and trend is given as:

$$
r_{t}=\mu+\beta t+\varepsilon_{t}
$$

The two modifications of (5) as in Enders and Lee (2012a and 2012b) for Fourier ADF [FADF] and Furuoka (2017) for Fourier ADF-Break point [FADF-SB] are specified in (6) and (7), respectively.

$$
\begin{aligned}
& r_{t}=\mu+\beta t+\gamma_{1} \sin (2 \pi k t / N)+\gamma_{2} \cos (2 \pi k t / N)+\varepsilon_{t} \\
& r_{t}=\mu+\beta t+\gamma_{1} \sin (2 \pi k t / N)+\gamma_{2} \cos (2 \pi k t / N)+\delta D U_{t}+\theta D\left(T_{B}\right)_{t}+\varepsilon_{t}
\end{aligned}
$$

where $\beta$ is slope parameter of trend term; $k$ represents the Fourier frequency, ranging from 1 to the optimal frequency; $\gamma_{1}$ and $\gamma_{2}$ measure the amplitude and displacement of the sinusoidal component of the deterministic term; $t$ represents the time/trend component; $\pi$ is a constant given as 3.1416. $N$ denotes the size of the sample chosen, while $\delta$ represents the slope parameter for the structural break dummy, $D U_{t}$, where $D\left(T_{B}\right)_{t}=1$ if $t=T_{B}$, otherwise $D\left(T_{B}\right)_{t}=0$.

$T_{B}$ reveals the point where structural break occurred; the slope parameter for the onetime break dummy is expressed as $\theta ; D\left(T_{B}\right)_{t}=1$ if $t=T_{B}$, otherwise $D\left(T_{B}\right)_{t}=0$; while $\mu$ is as earlier defined. Equations (6) and (7) are respectively the FADF, and FADF-SB unit root test models.

\subsubsection{Error Correction Forms of Fourier Alternative Hypotheses of Unit Root}

The error correction forms of (6) and (7), which also include augmentation components, are specified in (8) and (9). This is one aspect of our unit root detection analysis in the real exchange rate of Naira to foreign currency $\left(r_{t}\right)$. 


$$
\begin{aligned}
& \Delta r_{t}=\mu+\beta t+\gamma_{1} \sin (2 \pi k t / N)+\gamma_{2} \cos (2 \pi k t / N)+(\rho-1) r_{t-1} \\
& +\sum_{i=1}^{p} c_{i} \Delta r_{t-i}+\varepsilon_{t} \\
& \Delta r_{t}=\mu+\beta t+\gamma_{1} \sin (2 \pi k t / N)+\gamma_{2} \cos (2 \pi k t / N)+\delta D U_{t}+\theta D\left(T_{B}\right)_{t} \\
& +(\rho-1) r_{t-1}+\sum_{i=1}^{p} c_{i} \Delta r_{t-i}+\varepsilon_{t}
\end{aligned}
$$

where $p$ and $c$ in the augment denote the lag length for the augmentation and the slope parameter, respectively. The other parameters are as earlier represented. For parsimony and to align with the study objective, we set the lag length to unity. The selected optimal Fourier frequency $(k)$ is empirically determined by information criteria (Furuoka, 2017; Gil-Alana \& Yaya, 2020), but for simplicity of the estimation, it is restricted to 1 . The structural break date is represented as $\left(T_{B}\right)$.

\subsubsection{Nonlinear Fractional Unit Root Alternative Test Specifications}

This is another novel unit root technique employed to determine the validity of PPP in Nigeria. In line with Gil-Alana and Yaya, (2020), we extracted the two error correction forms of fractional unit root alternative tests from (6) and (7) by assuming that $d$ is an unknown fractional unit root value instead of unity as in (8) and (9). These two fractional unit root alternatives [nonlinear fractional unit root without break (NFrUR) and nonlinear fractional unit root with structural breaks (NFrUR-SB)] are specified in (10) and (11), respectively:

$$
\begin{aligned}
& \Delta^{d} r_{t}=\mu+\beta t+\gamma_{1} \sin (2 \pi k t / N)+\gamma_{2} \cos (2 \pi k t / N)+(\rho-1) \Delta^{d} r_{t-1} \\
& +\sum_{i=1}^{p} c_{i} \Delta^{d} r_{t-i}+\varepsilon_{t} \\
& \Delta^{d} r_{t}=\mu+\beta t+\gamma_{1} \sin (2 \pi k t / N)+\gamma_{2} \cos (2 \pi k t / N)+(\rho-1) \Delta^{d} r_{t-1} \\
& +\delta D U_{t}+\theta D\left(T_{B}\right)_{t}+\sum_{i=1}^{p} c_{i} \Delta^{d} r_{t-i}+\varepsilon_{t}
\end{aligned}
$$


Using binomial expansion, the fractional integration operator, $\Delta^{d}=(1-B)^{d}$, is truncated before employing least squares estimation technique. Gil-Alana and Yaya, (2020) found that the tests have robust sample properties. The estimation procedure of these tests follows the work of Robinson (1994) with constant, $\mu$ and trend, $t$ of which the null hypothesis is formalized as:

$$
H_{0}: d=d_{0}
$$

where, $d_{0}$ is any real value within a stationary and nonstationary range. The estimation approach is parametric, which guarantees the stationarity of the functional forms of $A R(1)$ or seasonal $A R M A$ processes. To enable the use of ordinary least squares (OLS) estimation technique with the Lagrange Multiplier (LM) test statistic, the disturbance process is assumed to be $I(0)$.

Gaussian Semiparametric (GSP) and Log-periodogram regression (GPH) techniques for estimating fractional unit root are utilized in this study. GSP uses maximum likelihood estimator in the frequency domain, which makes it a parametric approach in estimating fractional integration parameter.

\subsubsection{Fractional Cointegration Approach to PPP Validity}

The mean-reverting residual of the functional relation of the real exchange rate and relative prices is necessary for validating long run PPP. Mean-reverting residual means that the effect of a shock to the PPP relationship will fizzle out in a short time. This provides the justification for testing long-run PPP in fractional perspective.

The concept of cointegration was first proposed by Granger (1986) and Engle and Granger (1987). The Engle and Granger (1987) technique is widely used to test for cointegration due to its applicability and intuitive economic interpretations. In the Engle and Granger approach, I(0) residual suggests that the null hypothesis of no cointegration is rejected. However, Yin-Wong and Kon (1993) find that the equilibrium error being exactly $\mathrm{I}(0)$ is not a precondition for its mean reverting, meaning that fractionally integrated processes also display mean reversion. More importantly, Yin-Wong and Kon (1993) argue that a fractional analysis is more flexible in cap- 
turing a wider range of mean-reversion behaviour than the standard cointegration analysis, which makes it more robust in evaluating the long-run PPP.

As noted in Yaya, Gil-Alana, and Olubusoye (2017), a bivariate relation of $r$ and $q$ having the same order of integration $(\delta)$ have a long-run relationship if there exist $\alpha \neq 0$ such that $\alpha^{\prime} z_{t} \sim I(\gamma), \gamma<\delta$ and $z_{t}=\left(r_{t}, q_{t}\right)^{\prime}$. Thus, following Phillips (1991) and Yaya et al. (2017), the bivariate cointegrating relationship of the real exchange rate $(\mathrm{r})$ and relative prices $(\mathrm{q})$ is expressed as:

$$
\begin{aligned}
& r_{t}=v q_{t}+u_{1 t}(-\gamma), \\
& q_{t}=u_{2 t}(-\delta),
\end{aligned}
$$

for $t=0, \pm 1, \pm 2, \ldots$, where $u_{t}=\left(u_{1 t}, u_{2 t}\right)^{\prime}$ is a bivariate zero mean covariance stationary $I(0)$ unobservable process and $v \neq 0, \gamma<\delta$ both $r_{t}$ and $q_{t}$ are $I(\delta)$. Thus, in (13), $r_{t}-v q_{t}$ is covariance stationary. The parameter $v$ is estimated using the OLS in time or frequency domain with integer differentiation, but the properties of OLS vary considerably when estimated in fractional settings. Robinson (1994b) demonstrated that estimating $v$ using OLS with integer differentiation is inconsistent with the fractional setting when $\delta<0.5$.

Having confirmed the validity of long run PPP with the novel unit root and cointegration techniques, the PPP is computed using (2). The level of exchange rate misalignment is derived from the deviation of the nominal interbank exchange rate from the computed PPP by simply employing equation (15).

$$
m_{t}=P P P_{t}-r_{t}
$$

where $m_{t}$ and $P P P_{t}$ measure exchange rate misalignment and long run PPP (computed PPP) exchange rate at time $t$, respectively. If $m_{t}>0, r_{t}$ is overvalued, and if $m_{t}<0, r_{t}$ is undervalued. The exchanger rate is said to be in equilibrium when $m_{t}=0$.

\subsection{Results and Data Analysis}

\subsection{Classical unit root tests}

The result of the classical unit root test conducted on the real exchange rate of the 
Purchasing Power Parity Approach to Exchange Rate Misalignment in Nigeria

Nakorji et al.

Naira to Chinese Yuan (rc'), British Pound (ruk') and US Dollar (rus') are presented in Table 2. At a 5\% level of significance, the t-statistics obtained from the ADF, PP, and the KPSS tests reveal that the exchange rates are not stationary but integrated of order 1. This implies that the series are not cointegrated in the long run, thus refuting the existence of aPPP based on the classical unit root test. This result is consistent with the findings of Glenvill (2013) for South Africa and its five trading partners.

Table 2: Classical Unit Root Test Results

\begin{tabular}{lllllll}
\hline Variable & \multicolumn{2}{c}{ ADF } & \multicolumn{2}{c}{ PP } & \multicolumn{2}{c}{ KPSS } \\
& Level & 1st Diff. & Level & 1st Diff. & Level & 1st Diff. \\
& t stats & t stats & t stats & t stats & t stats & t stats \\
\hline rc' & -2.487 & $-10.811 * * *$ & -2.569 & $-11.125^{* * *} *$ & 0.270 & $0.065^{* *}$ \\
ruk' & -2.970 & $-10.994 * * *$ & -2.980 & $-11.107 * * *$ & 0.506 & $0.011^{* *}$ \\
rus' & -1.629 & $-10.054 * * *$ & -1.687 & $-10.052^{* * *}$ & 0.333 & $0.005^{* *}$ \\
\hline
\end{tabular}

These classical unit root results are based on the real exchange rates indexed on consumer prices

$* * *$ and $* *$ denote significance at $1 \%$ and $5 \%$ respectively.

\subsection{Linear Fractional Unit Root Test}

Based on the empirical evidence of Frankel (1986) and Taylor (1988) that classical unit root techniques are unreliable for validating PPP because of low power, this study, therefore, conducted the Gaussian Semiparametric (GSP) and Log-periodogram regression $(\mathrm{GPH})$ linear fractional unit root with nonlinear fractional unit root tests. In Table 3, the results of fractional I(d) based on GSP and GPH are presented. The fractional persistence estimates $\mathrm{d}$ was computed for three periodogram points

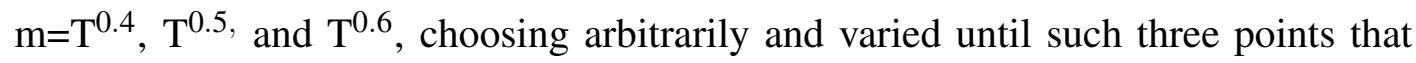
gave consistent results were reached. The confidence intervals for values of $d$ were also computed. For both fractional d estimation approaches, we found estimates of $\mathrm{d}$ in nonstationary range $(\mathrm{I}(\mathrm{d}>0.5))$ in most of the cases across the periodogram points, except in ruk where $\mathrm{d}$ values are found in both stationary and nonstationary mean reversion ranges. The mean reversion in ruk implies the possibility of this time series to revert to its mean values after a period of time. This is an indication that rPPP holds using Naira to UK Pound real exchange rate (ruk), aligning with the study by Crownover et al. (1996) that found support for rPPP in eight of fifteen countries. 
Table 3: Estimates of $d$ in the I (d) setting using both Log-Periodogram GPH and Whittle Semi-parametric approaches

\begin{tabular}{lllllll} 
Variables & \multicolumn{3}{l}{ Gaussian Semiparametric Estimate (GSP) } & \multicolumn{3}{l}{ Log-Periodogram Regression (GPH) } \\
& $\mathrm{m}=\mathrm{T}^{0.4}$ & $\mathrm{~m}=\mathrm{T}^{0.5}$ & $\mathrm{~m}=\mathrm{T}^{0.6}$ & $\mathrm{~m}=\mathrm{T}^{0.4}$ & $\mathrm{~m}=\mathrm{T}^{0.5}$ & $\mathrm{~m}^{0.5} \mathrm{~T}^{0.6}$ \\
\hline rc & 0.6790 & 0.7646 & 0.7230 & 0.8538 & 1.0833 & 0.8434 \\
& $(0.3086$, & $(0.4691$, & $(0.4920$, & $(0.1029$, & $(0.5474$, & $(0.4593$, \\
& $1.0494)$ & $1.0601)$ & $0.9540)$ & $1.6047)$ & $1.6191)$ & $1.2275)$ \\
\hline rus & 1.0153 & 1.0209 & 0.8580 & 1.3296 & 1.0878 & 0.8540 \\
& $(0.6449$, & $(0.7254$, & $(0.6270$, & $(0.5787$, & $(0.5520$, & $(0.4699$, \\
& $1.3857)$ & $1.3163)$ & $1.0890)$ & $2.0806)$ & $1.6236)$ & $1.2381)$ \\
\hline ruk & 0.7101 & 0.5367 & 0.6435 & 0.5376 & 0.3502 & 0.4462 \\
& $(0.3397$, & $(0.2412$, & $(0.4125$, & $(0.2133$, & $(0.1856$, & $(0.0620$, \\
& $1.0805)$ & $0.8322)$ & $0.8745)$ & $1.2885)$ & $0.8860)$ & $0.8303)$ \\
\hline
\end{tabular}

These results are based on the exchange rates computed with relative PPP. As indicated in Table 1, these results and those in Tables 4 and 5 are based on real exchange rate indexed on inflation rate in line with rPPP computation.

Note: The values in parentheses refer to the $95 \%$ confidence intervals for the differencing parameters.

\subsection{Fractional Cointegration Test}

A more advanced cointegration test for determining the long-run relationship by comparing two variables is conducted. In Table 4, the results of fractional cointegration based on Gil-Alana and Yaya (2020) approach are presented. Fractional cointegration technique based on this approach was carried out on paired variables rc and qc; rus and qus; and ruk and quk. By using a cointegrating regression model which simultaneously estimates fractional integration parameters $d$ for the long-run relationship and linear parameters of the model, $(\alpha$ and $\beta)$. These fractional integration parameters are found to be very small, close to zero in all cases, and are insignificant at $5 \%$ level in all the three cases of cointegration, though in some cases $\alpha$ and $\beta$ are significant. Non-rejection of zeros of the fractional order of long-run relationship and $I(1)$ evidence of individual time series indicates the possibility of fractional cointegration existing in paired cointegrating variables. Thus, providing further evidence of the existence of long-run PPP. 
Purchasing Power Parity Approach to Exchange Rate Misalignment in Nigeria

Nakorji et al.

Table 4: Fractional cointegration with uncorrelated errors.

\begin{tabular}{|c|c|c|c|}
\hline $\begin{array}{l}\text { Fractional Cointegrating } \\
\text { Variables }\end{array}$ & $D$ & $\alpha$ & $\beta$ \\
\hline $\mathrm{rc}$ and $\mathrm{qc}$ & $\begin{array}{l}0.1386 \\
(-0.0299,0.3070)\end{array}$ & $\begin{array}{l}0.2934 \\
(-0.0590)\end{array}$ & $\begin{array}{l}-24.8683 \\
(0.0000)\end{array}$ \\
\hline rus and qus & $\begin{array}{l}0.0026 \\
(-0.2022,0.2074)\end{array}$ & $\begin{array}{l}-0.0211 \\
(-0.9830)\end{array}$ & $\begin{array}{l}1.7756 \\
(-0.9800)\end{array}$ \\
\hline ruk and quk & $\begin{array}{l}-0.0887 \\
(-0.2687,0.0914)\end{array}$ & $\begin{array}{l}-0.7805 \\
(-0.4580)\end{array}$ & $\begin{array}{l}75.7999 \\
(-0.3700)\end{array}$ \\
\hline
\end{tabular}

Note: The values in parentheses refer to the $95 \%$ confidence intervals for the differencing parameter. $\alpha$ and $\beta$ are intercept and slope parameters of the Fractional cointegration relation.

To probe further the results in Table 4, the case of AR(1) error disturbance in the Gil-Alana and Yaya (2020) model was considered instead of the assumption of white noise disturbance. The essence was to cater for the possible serial correlation in the residuals, as it is expected in economic and finance time series. Also, monthly frequency series are liable to serial correlation issues (AR(1) errors). From the results presented in Table 5, we only observed invertible fractional-order $(-0.5<\mathrm{d}<0)$ and these are not significant at the 5\% level implying further evidence of fractional cointegration, supporting the long-run PPP in Nigeria. Our results corroborate the findings of Kargbo (2006) and Si Mohammed and Maliki (2015), who established long-run PPP in Africa and Algeria, respectively, using Johansen's cointegration methodology.

Table 5: Fractional cointegration with autocorrelated errors

\begin{tabular}{|c|c|c|c|}
\hline $\begin{array}{l}\text { Fractional Cointegrating } \\
\text { Variables }\end{array}$ & $d$ & $\alpha$ & $\beta$ \\
\hline $\mathrm{rc}$ and qc & $\begin{array}{l}-0.0914 \\
(-0.2722,0.0894)\end{array}$ & $\begin{array}{l}0.2921 \\
(0.0000)\end{array}$ & $\begin{array}{l}-24.6803 \\
(0.0000)\end{array}$ \\
\hline rus and qus & $\begin{array}{l}-0.2065 \\
(-0.4570,0.0440)\end{array}$ & $\begin{array}{l}-0.0061 \\
(-0.995)\end{array}$ & $\begin{array}{l}1.7759 \\
(-0.981)\end{array}$ \\
\hline ruk and quk & $\begin{array}{l}-0.2605 \\
(-0.5057,-0.0153)\end{array}$ & $\begin{array}{l}-0.893 \\
(-0.288)\end{array}$ & $\begin{array}{l}90.8176 \\
(0.226)\end{array}$ \\
\hline
\end{tabular}

Note: The values in parentheses refer to the $95 \%$ confidence intervals for the differencing parameters. $\alpha$ and $\beta$ are intercept and slope parameters of the Fractional cointegration relation with $A R(1)$. 


\subsection{Level of Exchange rate Misalignment}

Based on equation (2b) relative PPP is computed having tested its validity. Relative to PPP exchange rate, Figure 1 presents the level of under/over-valuation of Nigerian Naira-US Dollar interbank exchange rate.

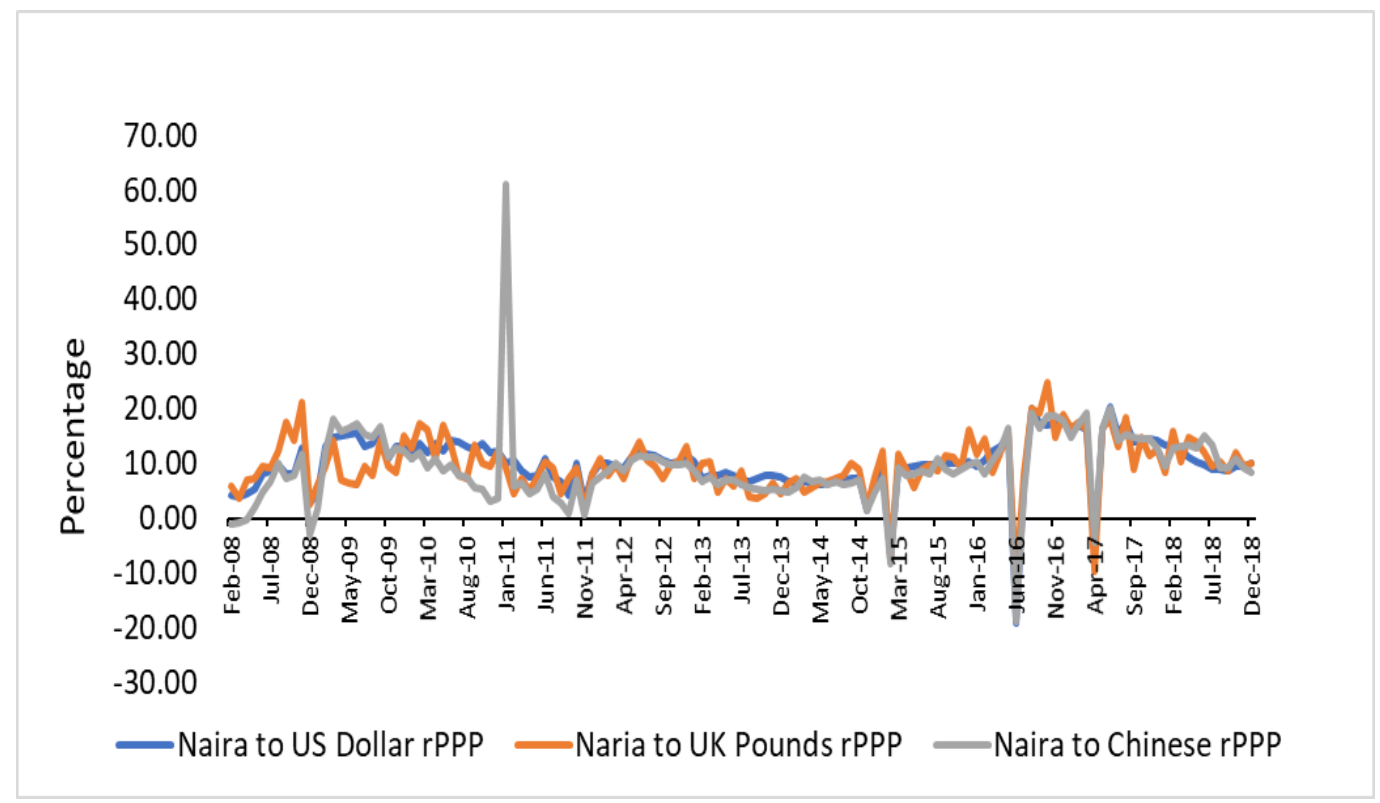

Figure 1: Under/Over-Valuation of Naira-US Dollar Exchange Rate

The level of exchange rate misalignment is shown in Figure 1. In line with Equation 15 , the points on the positive territory signify the periods the Naira was over-valued, while points on the negative territory indicate period the Naira was under-valued with respect to rPPP. Thus, the PPP computed with the relative PPP method shows that the interbank Naira to US Dollar, UK Pounds and Chinese Yuan exchange rates were over-valued in most of the study period. Specifically, visual inspection of the plot reveals that Naira to Yuan exchange rate was under-valued in February 2008, March 2008, December 2008, February 2015, June 2016 and April 2017, but remained overvalued in other periods. Similarly, Naira to Dollar and Pounds exchange rates relative to rPPP were under-valued in February 2015, June 2016 and April 2017 only, but remained over-valued in other periods. The under-valuation of the exchange rates of the Naira with respect to rPPP of the three currencies coincided in February 2015, June 2016 and April 2017. The under-valuation observed in June 2016 and April 
2017 coincided with periods the $\mathrm{CBN}$ moved to a more flexible exchange rate regime, and the commencement of foreign exchange transaction at the investors and exporters window, respectively. The policies seem to moderate the misalignment and curtail the level of over-valuation, but the effect was transient within a very short period as the rates became over-valued afterwards. As observed in Figure 1, the long period of over-valuation could have had some implications on the economy because, an over-valuation of the Naira implies that imports becomes cheaper. This tends to negatively affect the local industries as consumers shift from the consumption of local to foreign goods. Nigeria exports mainly oil, whose price is largely determined in the international market. As such, the benefits of over-valuing the currency cannot be adequately felt by Nigerians. Thus, there is the need to diversify the export base of the country with the view to appreciating the currency, given the long period of over-valuation of the Naira.

\section{Conclusion and Policy Recommendations}

This paper first applied the classical unit root testing techniques: ADF, PP and KPSS to investigate the existence of long-run PPP (aPPP) in Nigeria using interbank real exchange rate of the Naira to Chinese Yuan, British Pound and US Dollar for the period 2008:M1 to 2018:M12. The result shows that the real exchange rates computed based on consumer prices are not stationary, suggesting that the series are not cointegrated in the long run, thus refuting the existence of aPPP based on the classical unit root test. This result is in line with several other empirical literature which showed the impracticability of the aPPP approach to exchange rate determination.

The study further employed the nonlinear Fourier fractional unit root approach to account for smooth structural breaks in the presence of multiple shifts on the premise that nonlinearity and regime shift in a fractional unit root framework will provide a more robust insight into the validity of the PPP. The Gaussian Semiparametric and Log-periodogram regression with nonlinear fractional unit root tests found only the interbank Naira to British Pound real exchange rate to be mean reverting. This is an indication that PPP holds using Naira to UK Pound real exchange rate (ruk), which is applicable to rPPP. The results of fractional cointegration test provides further evidence of the existence of long-run PPP following the non-rejection of zeros of 
the fractional order of long-run relationship and I(1) evidence of paired cointegrating variables. This also confirms the existence of rPPP in Nigeria. In terms of diagnostic check, the AR(1) error disturbance in the Gil-Alana and Yaya (2020) model provides supporting evidence for the reliability of fractional cointegration result.

The exchange rates with the rPPP method shows that the interbank Naira to US Dollar, UK Pounds and Chinese Yuan exchange rates were over-valued in most of the study period. The exchange rates were under-valued in February 2015, June 2016 and April 2017. The period of under-valuation in June 2016 and April 2017 fell within the periods when $\mathrm{CBN}$ further liberalized the foreign exchange market and introduced the investors and exporters window. Given the consistency and empirical support for rPPP in Nigeria, the study, therefore, recommends its consideration for benchmarking exchange rate and gauging exchange rate misalignment in Nigeria. Furthermore, with the long period of over-valuation of the Naira at the foreign exchange market, there is need to diversify the export base of the economy with the view to appreciating the currency.

\section{References}

Adler, M., \& Lehmann, B. (1983). Deviations from purchasing power parity in the long-run. Journal of Finance, 38(5), 1471-1487

Alba, J. D., \& Papell, D. H. (2007). Purchasing power parity and country characteristics: Evidence from panel data tests. Journal of Development Economics, 83, 240-251.

Ali, A., Ajibola, I., Omotosho, B., Adetoba, O. O., \& Adeleke, A. (2015). Real exchange rate misalignment and economic growth in Nigeria. CBN Journal of Applied Statistics, $6,103-131$.

Alper, A., \& Kula, F. (2007). Examining the validity of PPP: The blackmarket exchange rate versus official rate. Journal of Economics and Business, 83-92.

Al-Zyoud, H. (2015). An empirical test of purchasing power parity theory for Canadian Dollar-US Dollar exchange rates. International Journal of Economics and Finance, 7 , 233-240.

Islam, A. M., \& Ahmed, S. M (1999). The purchasing power parity relationship: Causality and cointegration test using Korea-U.S. exchange rate and prices. Journal of Economic Development, 24(2), 95-111. 
Purchasing Power Parity Approach to Exchange Rate Misalignment in Nigeria

Nakorji et al.

Arize, A. C. (2011). Purchasing power parity in LDCs: An empirical investigation. Global Finance Journal, 22(1), 56-71.

Baharumshah, A. Z., \& Ariff, M. (1997). Purchasing power parity in Southeast Asian countries: A cointegration approach. Asian Economic Journal, 11, 141-153.

Bahmani-Oskooee, M. (1993). Purchasing power parity based on effective exchange rate and cointegration: 25 LDCs' experience with its absolute formulation. World Development, 21, 1023-1031.

Carnovale, C. (2001). Purchasing power parity and frequency domain filtering. National Library of Canada.

Cerrato, M., Kim, H., \& MacDonald, R. (2013). Equilibrium exchange rate determination and multiple structural changes. Journal of Empirical Finance, 22, 52-66. http://dx.doi.org/10.1016/j.jempfin.2013.03.001

Coakley, J. \& Snaith, S. (2004). Testing for long run relative purchasing power parity in Europe. Internet Review. Department of Accounting, Finance and Management, University of Essex.

Crownover, C., Pippenger, J., \& Steigerwald, D. G., (1996). Testing for absolute purchasing power parity. Journal of International Money and Finance 15, 783-796.

Cumby, R. E., \& Obstfeld, M. (1984). International interest rate and price level linkages under flexible exchange rates: A review of recent evidence. In Bilson, J. F. O. and Marston, R. C. eds.: Exchange Rate Theory and Practice (University of Chicago Press, Chicago, IL).

Dickey, D. A,. \& Fuller, W. A. (1979). Distribution of the estimators for autoregressive time series with a unit root. Journal of the American Statistical Association, 74, 427-431.

Dickey, D., \& Fuller, W. (1981). Likelihood ratio statistics for autoregressive time series with a unit root. Econometrica, 49, 1057-1072.

Diebold, F. X., \& Rudebusch, G. D. (1991). On the power of Dickey-Fuller test against fractional alternatives. Economics Letters, 35, 155-160.

Dornbusch, R. (1976). Expectation and exchange rate dynamics. Journal of Political Economy, 84, 1161-76. 
Enders, W., \& Lee, J. (2012a). A unit root test using a Fourier series to approximate smooth breaks. Oxford Bulletin of Economics and Statistics, 74, 574-599.

Enders, W., \& Lee, J. (2012b). The flexible Fourier form and Dickey-Fuller-type unit root tests. Economic Letters, 117, 196-199.

Ekong, C. N., \& Onye, K. U. (2013). The failure of the monetary exchange rate model for the Naira-Dollar. American Journal of Social and Management Sciences, 4, 8-19.

Engle, R., \& Granger, C. (1987). Cointegration and error correction representation, estimation and testing. Econometrica, 55, 251-276.

Essien, S. N., Uyaebo, S. O., \& Omotosho, B. S. (2017). Exchange rate misalignment under different exchange rate regimes in Nigeria. CBN Journal of Applied Statistics, 8, 1-21.

Frankel, J. A., \& Rose, A. K. (1995). A panel project on purchasing power parity: Mean reversion within and between countries. Journal of International Economics, 40, 20924.

Frenkel, J. A. (1976). A monetary approach to the exchange rate: Doctrine aspects and empirical evidence. The Scandinavian Journal of Economics, 78, 200-224

Furuoka, F. (2017). A new approach to testing unemployment hysteresis. Empirical Economics 53, 1253-1280.

Granger, C. W. J. (1986). Developments in the study of cointegrated economic variables. Oxford Bulletin of Economic Statistics, 48, 213-228.

Gil-Alana, L. A., \& Yaya, O. S. (2020). Testing fractional unit roots with non-linear smooth break approximations using Fourier functions. Journal of Applied Statistics, , 1-18. https://doi.org/10.1080/02664763.2020.1757047

Glenville, R. (2013). Inflation and the purchasing power parity in South Africa. Journal of Applied Business and Economics, 8, 169-191

Hassler, U., \& Wolters, J. (1994). On the power of unit root tests against fractional alternatives. Economic Letters, 45, 1-5.

Haikko, C. (1992). Is the purchasing power parity a useful guide to the Dollar? Economic Review, Federal Reserve Bank of Kansas City, 77, 37-51.

Israd, P. (1977). How far can we push the law of one price. American Economic Review, 942-948. 
Juan, C. C., Estefania, M., \& Paulo, J. R. (2018). Real exchange rate misalignments in CEECs: Have they hindered growth? Working Paper Series 5/2018

Johansen, S., \& Juselius, K. (1990). Maximum Likelihood Estimation and Inferences on Cointegration - with Applications to the Demand for Money. Oxford Bulletin of Economics and Statistics, 52, 169-210.

Kalsoom A. (2014). Purchasing power parity: Implication with respect to Pakistan and USA. Research Journal of Finance and Accounting, 5, 193-201.

Si Mohammed, K., \& Maliki S. (2015). An empirical test of purchasing power parity of the Algerian exchange rate: Evidence from panel dynamic. European Scientific Journal, $11,19-27$.

Kargbo, J. M. (2003). Cointegration tests of purchasing power parity in Africa. World Development, 31, 1673-1685.

Kargbo, J. M. (2004). Purchasing power parity and exchange rate policy reforms in Africa. South African Journal of Economics, 72, 258-281.

Kargbo, J. M. (2006). Purchasing power parity and real exchange rate behaviour in Africa. Applied Financial Economics, 16(1-2), 169-183.

Kilian, L., \& Taylor, M. (2003). Why is it difficult to beat the random walk forecast of exchange rates? Journal of International Economics, 60, 85-107

Krichene, N. (1998). Purchasing power parities in five East African countries: Burundi, Kenya, Rwanda, Tanzania, and Uganda. IMF Working Paper No 98/148

Krugman, P. (1978). Purchasing power parity and exchange rates. Journal of International Economics, 8(3) 397- 407.

Lee, J., \& Strazicich, M. (2013). Minimum LM unit root test with two structural break. Economics Bulletin, 33, 2483-2492.

Mark, N, (1990). Real and nominal exchange rate in the Long Run: An empirical Investigation. Journal of International Economics, 28, 115-36.

McChesney F., Shughart, W., \& Haddock, D. (2004). On the internal contradictions of the law of one price. Economic Inquiry, 706-716.

Merza, E. (2017). The validity of the purchasing power parity hypothesis for Kuwait.Modern Applied Science, 11, 188-194. 
Mohammed, K. S. (2016). An empirical test of purchasing power parity theory for Euro and US Dollar vs the Algerian exchange rate. MPRA Paper No. 75285, Online at https://mpra.ub.uni-muenchen.de/75285/

Nusair, S. (2003). Testing the validity of purchasing power parity for Asian countries during the current float. Journal of Economic Development, 28, 129-147.

Obaseki, P. J. (1998). The Purchasing power parity measure of Naira's equilibrium exchange rate. CBN Economic and Financial Review, 36 ,1-21.

Officer, L. H. (2006). Purchasing power parity: From Ancient Times to World War II. Economic History Services, EH.Net (forthcoming)

Ononugbo, M. C. (2005). Purchasing power parity and exchange rate in Nigeria: A regime switching approach.CBN Economic and Financial Review, 43(2), 1.

Oxford Reference (2021). Oxford University Press.

Pakko, M. R., \& Pollard, P. S. (1996). For here or to go? Purchasing power parity and the Big Mac. Federal Reserve Bank of St Louis Review, 78, 3-22.

Perron, P. (2006). Dealing with Structural Breaks. In Palgrave Handbook of Econometrics, Vol. 1: Econometric Theory, K. Patterson and T. C. Mills (eds.), Palgrave Macmillan, 1(2) 278-352.

Phiri, A. (2014). Purchasing power parity (PPP) between South Africa and her main currency exchange partners: Evidence from asymmetric unit root tests and threshold cointegration analysis. MPRA Paper No. 53659, posted 14 February 2014.

Qayyum, A., Khan, M. A., \& Khair-u-Zaman (2004). Exchange rate misalignment in Pakistan: Evidence from purchasing power parity theory The Pakistan Development Review, 43, 4/2, 721-735

Lafrance, R. \& Schembri, L. L. (2002). Purchasing-Power Parity: Definition, Measurement, and Interpretation. Bank of Canada Review, Bank of Canada, 2002(Autumn), 27-33.

Robinson, P. M. (1994). Efficient tests of nonstationary hypotheses. Journal of the American Statistical Association, 89, 1420-1437.

Roll, R.(1979). Violations of purchasing power parity and their implications for efficient international commodity markets. In Marshall Sarnat and Giorgio Szego, eds.: International Finance and Trade (Ballinger, Cambridge, MA) Salvatore, (1993). International Economics. New Jersey Prentice- Hall 
Purchasing Power Parity Approach to Exchange Rate Misalignment in Nigeria

Nakorji et al.

Sarno, L., \& Taylor, M. (2002). Purchasing power parity and the real exchange rate. IMF Staff Papers, 49, 65-105

Shirley, I. (2013). Testing Purchasing Power Parity in the Long-run. Journal of Applied Business and Economics, 14, 11-20.

Suranovic, S. M. (1999). International Finance Theory and Policy. https://open.umn.edu/opentextbooks/textbooks/18

Stephen, B. A., \& Sanni, O. (2011). The exchange rate determination in Nigeria: The purchasing power parity option. Mathematical Theory and Modelling. 1(2), 5-22.

Taylor, A. M. (2002). A century of purchasing-power parity. The Review of Economics and Statistics, 84, 139-150

Taylor, M. P. (1988). An empirical examination of long-run purchasing power parity using cointegration techniques. Applied Economics, 20, 1369-81.

Taylor, M. P (1995). The economics of exchange rate. Journal of Economic Literature, 33, $13-47$.

Taylor, A. M., \& Taylor, M. P. (2004). The purchasing power parity debate. Journal of Economic Perspectives, 18(4), 135-158.

Tipoy C. K., Breitenbach, M. C., \& Zerihun, M. F., (2018). Exchange rate misalignment and economic growth: Evidence from nonlinear panel cointegration and Granger causality tests. Studies in Nonlinear Dynamics and Econometrics, De Gruyter, 22(2), 1-16, April

Voinea, L. G. (2013). The Purchasing Power Parity from the Great Financial Crisis. Madrid: Universidad Complutense.

Wickremasinghe, G. B. (2004). The Sri Lankan Rupee and purchasing power parity during the current floating period. International Trade 0406005, University Library of Munich, Germany.

World Bank (2013). Measuring the Real Size of the World Economy: The Framework, Methodology, and Results of International Comparison Program. The World Bank.

Yaya, O. S., Gil-Alana, L. A., \& Olubusoye, O. E. (2017). The global financial crisis: Testing for fractional cointegration between the US and Nigerian stock markets. The Journal of Developing Areas, 51(4), 29-47. 
Yin-Wong, C., \& Lai. K. S. (1993). A fractional cointegration analysis of purchasing power parity. Journal of Business and Economics Statistics. 11, 103-112

Yildirim, D. (2017). Empirical investigation of purchasing power parity for Turkey: Evidence form recent nonlinear unit root test. Central Bank Review, 17(2), 39-45.

Zayed, N. M., \& Zahan, N. A. (2017). An Analysis of purchasing power parity (PPP) using Ricardian model regarding real exchange rate, inflation and import of Bangladesh. Australian Academy of Accounting and Finance Review, 3, 111-118.

Zerihun, M. F., Breitenbach, M. C. (2016). Nonlinear approaches in testing PPP: Evidence from Southern African Development Community. Economic Modelling, 56, 162-167, ISSN 0264-9993, https://doi.org/10.1016/j.econmod.2016.04.002. 